\title{
The Causality Link Between Electricity Consumption and Economic Growth in Turkey: Evidence from ARDL Bounds Testing Procedure
}

\author{
Uğur Korkut Pata
}

\author{
Harun Terzi ${ }^{\mathrm{b}}$
}

\begin{abstract}
Electricity consumption is regarded as an indicator of welfare in both developing and developed countries. In this study, the causality link between net electricity consumption and economic growth in the Turkish economy is investigated by the 55 annual observations covering the period from 1960 to 2014. According to the results of UVAR and ARDL analysis resolved with both AIC and SIC information criteria, there is a positive unidirectional and statistically significant causality moving from net electricity consumption to economic growth in the short/long run. The empirical results indicate that the energy led-growth hypothesis is valid for Turkey, that is growing net electricity consumption positively stimulates the economic growth in the short/long run.
\end{abstract}

Keywords: Electricity Consumption, Economic Growth, ARDL, Bounds Test, Turkey

JEL Classification: C22, Q43, Q48

\section{Introduction}

The level of energy production and consumption is widely accepted as an important indicator to stimulate the level of socio-economic development process (Ghosh, 2002: 125). The International Energy Agency (IEA) (2016) also reports that energy is the primary factor of the production and economic growth in the developing countries, and Turkey's energy demand is the fastest growing one among the member countries. Several analytical studies mostly dealt with the different types of energy sources (renewable hydro, solar, geothermal, nonrenewable -gas, oil and coal) and economic growth relations in the literature emphasized the interaction between energy and growth to better understand the causality link between them. However, a limited number of some studies mainly focused on the association between electricity consumption (EC) and economic growth $(\mathrm{Y})$ in a causality manner (cause and effect) in developed and developing countries. According to World Development Indicators (WDI) (2016), Turkey as a developing country with a population of 79.3 million people equivalent to the $1.1 \%$ of the whole World population is listed as the 18th biggest economy in the world by GDP. Due to relatively high growth rate of the urbanizing population and economic activities, the energy demand of Turkey is increasing rapidly year by year. Turkey's annual percentage growth rate of GDP is 4.5\% (5.4) from 1960 to 2014 (2010 to 2014). Over the same period, the growth rate of net EC is $8.7 \%$ yearly on average. In the last five years, average growth rate of net EC is $5.8 \%$.

\footnotetext{
${ }^{a}$ Res. Assist., Karadeniz Technical University, Faculty of Economics and Administrative Sciences, Department of Economics, Trabzon, Turkiye, korkutpata@ktu.edu.tr

bProf. Dr., Karadeniz Technical University, Faculty of Economics and Administrative Sciences, Department of Economics, Trabzon, Turkiye, hterzi@ktu.edu.tr
} 
The Turkish Ministry of Energy and Natural Resources (MENR) (2014) reports that electricity demand has steadily increased and gross EC is estimated to increase by about $6 \%$ per year for next 5 years. Turkey's gross EC in 2000, 2005, 2010, 2014 was 128, 160, 210, 257 billion kWh. Furthermore, it is only since the last 15 years, the gross EC has increased nearly $100 \%$. The Turkish Ministry of Foreign Affairs (2016) reports that Turkey became the second country after the China, in terms of electricity demand increase in the World since in 2005. Turkey currently produces only $26 \%$ of total EC by domestic resources, the most of the energy demand is provided by imports. As of 2014 in Turkey, the share of natural gas, coal and hydro in total electricity production are 121,76 and 41 billion $\mathrm{kWh}$. At present, around $48 \%$ of total electricity production relies directly on imported natural gas (TEIAS, 2014: 13). Due to continuously increasing EC and demand, Turkey is considered as one of the dynamic energy dependency economies. The total net EC of Turkey can be divided into five sectors in 2014 -housing, service-commerce, government, public street lighting and industry. The consumption from the housing represents $22.3 \%$ ( 46 billion $\mathrm{kWh}$ ) of overall consumption, the service-commerce sector 19.2\% (40 billion $\mathrm{kWh}$ ), the government sector 3.9 ( 8.1 billion $\mathrm{kWh}$ ), $1.9 \%$ (4 billion $\mathrm{kWh}$ ) street lighting and $\mathbf{4 7 . 2 \%}$ (98 billion kWh) industry sector. Electricity is the largest (almost 50\%) energy source for industry. In order to increase domestic electricity supply, to generate a more reliable and competing energy market, Turkey issued the Electricity Market Law numbered as 4628 in 2001 and the Electricity Market Law numbered 6446 (EML) in 2013 (TETAS, 2014: 9). Due to privatization and encouraging private investors, Turkey steadily increased the share of the private investors in electricity production and privatized thermoelectric and hydroelectric plants. After the Electricity Market Laws and new regulations in liberalization programs, the share of electricity produced by the private sector increased from $57 \%$ in 2003 to $72 \%$ in 2014 .

The study is organized as follows: the first part presents some crucial points regarding the causality link between $\mathrm{Y}$ and $\mathrm{EC}$ in the Turkish economy. The second part overviews the period of data, methods and findings of the relevant empirical studies undertaken in both Turkey and various countries. The third part explains the data and the fourth part describes short summary of econometric methods to conserve space. The technical details of the methods can be found in the related articles. The fifth part lists empirical findings and diagnostic tests. Then the final sixth part presents a short summary, conclusions and suggestions to the policy makers.

\section{Literature Review}

Regarding the causality link between EC and $Y$ there are four alternative hypotheses: 1) Growth hypothesis: EC Granger causes Y; 2) Feedback hypothesis: EC and Y Granger cause each other; 3) Conservation hypothesis: Y Granger causes EC; 4) Neutrality hypothesis: EC and Y do not Granger cause each other. The feedback and growth hypothesis implies that energy promotion policies stimulate economic growth and energy conservation policies has a negative effect on economic growth. However, neutrality hypothesis claims that energy conservation policies can not harm economic growth.

In the literature, there have been many studies, which highlight the causality between $\mathrm{Y}$ and EC. As indicated in Table 1, the empirical findings of 15 studies on the causality link between EC and $Y$ for Turkey have been mixed. To our knowledge, only 1 (6) study supporting feedback hypothesis found a bidirectional causality in the short (long) run, 6 (4) studies supporting growth hypothesis found a unidirectional causality moving from EC to $Y$ in the short (long) run, 3 (2) studies supporting conservation hypothesis found a unidirectional causality is moving from $Y$ to $E C$ in the short (long) run. The results of different studies seem to be in conflict due to employing alternative causality tests-procedures, time periods and data sets. However, the majority of the studies supports the existence of both a long-run causality link and a bidirectional causality link between $Y$ and EC which confirms the feedback hypothesis in Turkey. Although the causality results are mixed in Turkey, overall, the majority of the studies supports at least a positive unidirectional causality relation between $\mathrm{Y}$ and EC. The study differs from earlier studies in Turkey from two aspects: First, it utilizes a longest annual data available after the period of 1960; second it employs net total EC. In the literature review, the empirical findings of selected total 34 studies 15 out of 34 researches are related to Turkey and the rest of them are related to the various countries' experiences -concerning the 
causality link between EC and Y. In Table 1, while 12 out of 15 studies applied causality link between $\mathrm{Y}$ and $\mathrm{EC}$ in a bivariate framework.

Table 1. A List of Papers Analyzing the Causality Link Between $Y$ and EC in Turkey

\begin{tabular}{|c|c|c|c|}
\hline Author (s) & Period & Causality & Method \\
\hline Terzi (1998) & 1950-1991 & $\mathrm{EC} \leftrightarrow \mathrm{Y}^{\mathrm{LR}}$ & EG-Cointegration, ECM \\
\hline Altınay \& Karagol (2005) & $1950-2000$ & $E C \rightarrow Y S R$ & $\begin{array}{l}\text { DL VAR, Pair-Wise Granger } \\
\text { causality }\end{array}$ \\
\hline $\begin{array}{c}\text { Karagol, Erbaykal \& Ertuğrul } \\
\text { (2007) }\end{array}$ & 1974-2004 & $\begin{array}{l}E C-\rightarrow Y^{L R} \\
E C+\rightarrow Y^{S R}\end{array}$ & ARDL, Bounds Test, UECM \\
\hline $\begin{array}{l}\text { Soytas \& Sarı } \\
(2007)\end{array}$ & $1968-2002$ & $E C \rightarrow Y^{L R}$ & $\begin{array}{l}\text { JJ-Cointegration, VECM, } \\
\text { IR-VD }\end{array}$ \\
\hline Aktas \& Yılmaz (2008) & 1970-2004 & $\begin{array}{l}\mathrm{EC} \leftrightarrow \mathrm{Y}^{L R} \\
\mathrm{Y} \rightarrow \mathrm{EC}^{\mathrm{SR}}\end{array}$ & $\begin{array}{c}\text { JJ-Cointegration, } \\
\text { ECM }\end{array}$ \\
\hline Acaravci (2010) & $1968-2005$ & $\begin{array}{l}E C \rightarrow Y^{L R} \\
E C \rightarrow Y^{S R}\end{array}$ & $\begin{array}{l}\text { JJ-Cointegration, VECM } \\
\text { Granger causality }\end{array}$ \\
\hline Acaravci \& Ozturk (2012) & $1968-2006$ & $\begin{array}{l}E C \rightarrow Y^{L R} \\
E C \rightarrow Y^{S R}\end{array}$ & ARDL, Bounds Test, ECM \\
\hline $\begin{array}{l}\text { Yapraklı \& Yurttancıkmaz } \\
\text { (2012) }\end{array}$ & $1970-2010$ & $\mathrm{EC} \leftrightarrow \mathrm{Y}^{\mathrm{LR}}$ & $\begin{array}{l}\text { JJ-Cointegration, } \\
\text { ECM }\end{array}$ \\
\hline Aslan (2014a) & $1968-2008$ & $\mathrm{EC} \leftrightarrow \mathrm{Y}^{\mathrm{LR}}$ & ARDL, Bounds Test, UECM \\
\hline Aslan (2014b) & $1968-2008$ & $\mathrm{EC} \leftrightarrow \mathrm{Y}^{\mathrm{LR}}$ & ARDL, Bounds Test, \\
\hline $\begin{array}{l}\text { Topallı \& Alagoz } \\
\text { (2014) }\end{array}$ & 1970-2009 & $\begin{array}{l}\mathrm{Y} \rightarrow \mathrm{EC} C^{\mathrm{R}} \\
\mathrm{Y} \rightarrow E \mathrm{ECR}^{S R}\end{array}$ & $\begin{array}{l}\text { JJ-Cointegration, VECM } \\
\text { TY Granger causality }\end{array}$ \\
\hline $\begin{array}{c}\text { Nazlıoglu, Kayhan \& Adiguzel } \\
\text { (2014) }\end{array}$ & $1967-2007$ & $\begin{array}{c}\mathrm{ECL} \leftrightarrow \mathrm{Y}^{\mathrm{SR}-\mathrm{LR}} \\
\mathrm{EC} \neq \mathrm{Y}^{\mathrm{NL}}\end{array}$ & $\begin{array}{l}\text { Linear and Non-Linear Granger } \\
\text { causality }\end{array}$ \\
\hline $\begin{array}{l}\text { Pempetzoglu } \\
\text { (2014) }\end{array}$ & $1945-2006$ & $\begin{array}{l}\mathrm{YL} \rightarrow E C^{S R} \\
\mathrm{Y} \rightarrow E C^{N L}\end{array}$ & $\begin{array}{l}\text { Linear causality and } \\
\text { NL-DP causality }\end{array}$ \\
\hline Gokten \& Karatepe (2016) & $1950-2010$ & $\mathrm{EC} \rightarrow \mathrm{YSR}$ & DL-Granger causality \\
\hline Pata \& Terzi (2016) & $1972-2011$ & $\mathrm{EC} \rightarrow \mathrm{YSR}$ & DL-Granger causality, SUR \\
\hline
\end{tabular}

Note: All studies were based on annual data. $Y \rightarrow E C(E C \rightarrow Y)$ : causality runs from $Y$ to $E C(E C$ to $Y)$. $E C \leftrightarrow Y$ : bidirectional causality. $\neq$ : no causality. SR-LR: Short run-long run. L: Linear Granger Causality. NL: NonLinear Granger Causality. DP: Disk and Panchenko. EG: Engle-Granger. DL: Dolado-Lütkepohl. JJ: Johansen-Juselius. ECM: Error Correction Model. UECM: Unrestricted Error Correction Model. VECM: Vector Error Correction Model. ARDL: Autoregressive Distributed Lag Model. SUR: Seemingly Unrelated Regression.

The methods and empirical findings analyzing the causality link between EC and $\mathrm{Y}$ in Turkey are summarized shortly, in a chronological way, as follows:

Terzi (1998) carried out one of the pioneering studies by using the EG- cointegration test and ECM, covering sectoral data from 1950 to 1991. The results from the use of bivariate causality analysis indicated that there is a positive bidirectional causality between $\mathrm{Y}$ and EC in both aggregate and commercial-industrial levels, and he concluded that EC and $Y$ directly stimulate each other. Therefore, government should increase electricity demand/supply to keep economic growth upward and to prevent an economic slowdown in times of energy shortages. Altmay \& Karagol (2005) utilized the DL VAR and pairwise Granger causality methods based on data from 1950 to 2000 and found a unidirectional causality moving from total EC to real $Y$ but not the vice versa. Karagol, Erbaykal \& Ertuğrul (2007) employed UECM-ARDL models and bounds test approach for cointegration and causality over the period of 1974-2004 and reached the conclusion that a positive (respectively negative) unidirectional causality is moving from EC to $Y$ growth rate in the short run (respectively in the long run). Soytas \& Sarı (2007) used JJ-cointegration test and VECM by employing data from 1968 to 2002 and found that variables are cointegrated and a positive unidirectional causality is moving from EC in industry to value added-GNP manufacturing. They concluded that energy is an essential input for overall production. Aktas \& YIImaz (2008) used JJ-cointegration test and ECM covering the period of 19702004 and found that variables are cointegrated and a positive unidirectional (respectively bidirectional) 
causality is moving from GNP to EC in the long run (respectively short run). They reached the conclusion that activities in industrial/commercial sectors are based on energy inputs, and country needs to increase its capacity of electricity production. Acaravcı (2010) investigated the short/long run causality between EC and $Y$ with structural breaks covering the period of 1968-2005 by employing the JJ-cointegration test and VECM. They concluded that variables are cointegrated and a unidirectional causality is moving from EC to Y. Acaravci \& Ozturk (2012) utilized ARDL bounds test and ECM over the periof of 1968-2006 and their findings show that a unidirectional causality is moving from per capita EC to per capita GDP in the short/long run.

Yapraklı \& Yurttancıkmaz (2012) used the data for the period of 1970-2010 by the JJ-cointegration test and ECM and concluded that there is a bidirectional causality between cointegrated variables, $Y$ and total EC therefore, Turkey has to increase energy supply to sustain its economic growth. Aslan (2014a-b) analyzed data for the period of 1968-2008 by the ARDL bounds test, UECM and his findings support feedback (respectively neutrality) hypothesis that there is a positive bidirectional causality between cointegrated per capita $Y$ and total EC variables in the long (respectively short) run. Topallı \& Alagoz (2014) used the sample from 1970 to 2009 by applying the VECM, JJ-cointegration and causality tests and concluded that in the short/long run, a unidirectional causality is moving from real $\mathrm{Y}$ to $\mathrm{EC}$ therefore, energy conservation policies may not unfavorable effects on economic growth.

Nazlıoglu, Kayhan \& Adiguzel (2014) utilized three methods- the bounds, linear and non-linear (NL) Granger causality tests for the period of 1967-2007 and found that in the linear causality models there is a bidirectional causality between cointegrated $\mathrm{Y}$ and $\mathrm{EC}$ variables in the short/long run, however, there is no any causality link in the NL causality model. They paid more attention to the findings of NL causality models than the linear ones by accepting the validity of the neutrality hypothesis, and concluded that the level of EC has no any effect on economic growth in Turkey. Pempetzoglu (2014) analyzed the causal link between EC and $Y$ for the period of 1945-2006 by employing the standard linear and NL-PD Granger causality tests. She found that a unidirectional linear causality is moving from $Y$ to EC at both aggregate and sectoral (residential, commercial and street illumination EC) levels, but a unidirectional NL causality is moving from commercial EC towards $Y$ and from $Y$ to EC for street illumination. Pata and Terzi (2016) employed Dolado-Lütkepohl Granger causality with SUR method from the period 1972 to 2011 and found that a positive unidirectional causality is moving from EC to GDP in the short run. Gokten and Karatepe (2016) used the data for the period of 1950-2010 by Dolado-Lütkepohl Granger causality, and concluded that there is a unidirectional causality is going from EC to GDP in the short run.

Soytas \& Sarı (2006), Acaravci \& Ozturk (2012) and Aslan (2014b) utilized a multivariate causality analysis to find the direction of Granger causality amongst variables in the short/long run. Soytas \& Sarı (2006) developed a VECM causality model based on the four variables (total employment, total EC, total value added-GNP and total fixed investment) in the manufacturing industry, Acaravci \& Ozturk (2012) and Aslan (2014b) employed an ARDL model consisting three variables (EC, Y and labor force). Except the studies of Nazlıoglu, Kayhan \& Adiguzel (2014) and Pempetzoglu (2014) utilized both linear and NL (nonlinear) causality tests, the rest of the studies employed only linear causality tests.

The empirical findings of the 19 selected recent studies listed in Table 2 above in the various countries are shortly summarized as follows: Seven studies have concluded causality is moving from EC to Y. Such studies are Shiu \& Lam (2004) for China, Yuan, Zhao, Yu \& Hu (2007) for China, Akinlo (2009) for Nigeria, Chadran, Sharma \& Madhavan (2010) for Malaysia, Ahamad \& Islam (2011) for Bangladesh, Lyke (2015) for Nigeria, Kumar, Stauvermann \& Patel (2015) for Gibraltar. On the contrary, seven studies have concluded causality is moving from $Y$ to EC. Such studies are Ghosh (2002) for India, Jumbe (2004) for Malawi, Narayan \& Smyth (2005) for Avusturalia, Mozumder \& Marathe (2007) for Bangladesh, Shahbaz, Tang \& Shabbir (2011) for Portugal, Shahbaz \& Feridun (2011) for Pakistan, Ogundipe, Akinyemi \& Ogundipe (2016) for Nigeria. 
Table 2. Electricity Consumption and Economic Growth Studies in the Various Countries

\begin{tabular}{|c|c|c|}
\hline Author(s) Country-(Period) & $\begin{array}{l}\text { Way of } \\
\text { Causality }\end{array}$ & Methods and Variables \\
\hline $\begin{array}{c}\text { Ghosh (2002), } \\
\text { India, (1950-1997) }\end{array}$ & $\mathrm{Y} \rightarrow \mathrm{EC}$ & $\begin{array}{l}\text { JJ-Cointegration, Granger causality, per capita Y and } \\
\text { EC }\end{array}$ \\
\hline $\begin{array}{l}\text { Jumbe (2004), } \\
\text { Malawi, (1970-1999) }\end{array}$ & $\mathrm{Y} \rightarrow \mathrm{EC}$ & $\begin{array}{l}\text { Granger Causality, ECM, Y } \\
\text { and total EC }\end{array}$ \\
\hline $\begin{array}{l}\text { Shiu \& Lam (2004), } \\
\text { China, (1971-2000) }\end{array}$ & $E C \rightarrow Y$ & $\begin{array}{l}\text { JJ-Cointegration, ECM, Y } \\
\text { and total EC }\end{array}$ \\
\hline $\begin{array}{c}\text { Narayan \& Smyth (2005), Avusturalia, } \\
\text { (1966-1999) }\end{array}$ & $\mathrm{Y} \rightarrow \mathrm{EC}$ & $\begin{array}{l}\text { ARDL, Bounds test, UECM, } \\
\text { per capita } Y \text { and total EC }\end{array}$ \\
\hline $\begin{array}{c}\text { Yoo (2005), } \\
\text { Korea, (1970-2002) } \\
\end{array}$ & $\mathrm{Y} \leftrightarrow \mathrm{EC}$ & $\begin{array}{l}\text { JJ-Cointegration, ECM } \\
\text { Y and total EC }\end{array}$ \\
\hline $\begin{array}{c}\text { Mozumder \& Marathe (2007), Bangladesh, (1971- } \\
\text { 1999) }\end{array}$ & $\mathrm{Y} \rightarrow \mathrm{EC}$ & $\begin{array}{l}\text { JJ-Cointegration, VECM, } \\
\text { per capita } \mathrm{Y} \text { and EC }\end{array}$ \\
\hline $\begin{array}{l}\text { Yuan, Zhao, Yu \& Hu (2007), } \\
\text { China, (1978-2004) }\end{array}$ & $E C \rightarrow Y$ & $\begin{array}{l}\text { JJ-Cointegration, ECM, } \\
\text { HP Filter, Y and total EC }\end{array}$ \\
\hline $\begin{array}{c}\text { Akinlo (2009), } \\
\text { Nigeria, (1980-2006) } \\
\end{array}$ & $E C \rightarrow Y$ & $\begin{array}{l}\text { JJ-Cointegration, ECM, } \\
\text { HP Filter, Y and total EC }\end{array}$ \\
\hline $\begin{array}{l}\text { Chadran, Sharma \& Madhavan (2010), Malaysia, } \\
\text { (1971-2003) }\end{array}$ & $E C \rightarrow Y$ & $\begin{array}{c}\text { JJ-EG Cointegration, ARDL, Bounds test, UECM, } \\
\text { Y and total EC }\end{array}$ \\
\hline $\begin{array}{l}\text { Ouedraogo (2010), } \\
\text { Burkina Faso, (1968-2003) }\end{array}$ & $\mathrm{Y} \leftrightarrow \mathrm{ECLR}$ & $\begin{array}{c}\text { JJ-Cointegration, ARDL, Bounds test, VECM, Granger } \\
\text { causality, } \\
\text { Y and total EC }\end{array}$ \\
\hline $\begin{array}{l}\text { Ahamad \& Islam (2011), Bangladesh, } \\
\text { (1971-2008) }\end{array}$ & $\begin{array}{c}E C \leftrightarrow Y L R \\
E C \rightarrow Y\end{array}$ & $\begin{array}{l}\text { JJ-Cointegration, VECM, } \\
\text { per capita } Y \text { and total EC }\end{array}$ \\
\hline $\begin{array}{c}\text { Kouakou (2011), } \\
\text { Ivory Coast, (1971-2008) }\end{array}$ & $\mathrm{Y} \leftrightarrow \mathrm{EC}$ & $\begin{array}{l}\text { ARDL, Bounds test, UECM, } \\
\text { per capita } Y \text { and total EC }\end{array}$ \\
\hline $\begin{array}{c}\text { Shahbaz, Tang \& Shabbir (2011), } \\
\text { Portugal, (1971-2009) }\end{array}$ & $\begin{array}{c}E C \leftrightarrow Y L R \\
Y \rightarrow E C\end{array}$ & $\begin{array}{c}\text { ARDL, Bounds test, UECM, } \\
\text { Y and total EC }\end{array}$ \\
\hline $\begin{array}{l}\text { Gurgul \& Lach (2012), Poland, } \\
\text { (2000q1-2009q4) }\end{array}$ & $\mathrm{Y} \leftrightarrow \mathrm{EC}$ & Toda Yamamoto, NL Granger Causality, Y and total EC \\
\hline $\begin{array}{c}\text { Shahbaz \& Feridun (2011), Pakistan, } \\
\text { (1971-2008) }\end{array}$ & $\mathrm{Y} \rightarrow \mathrm{EC}$ & $\begin{array}{l}\text { ARDL, Bounds test, VECM, } \\
\text { TY VAR, per capita Y and EC }\end{array}$ \\
\hline $\begin{array}{l}\text { Tang \& Tan (2013), } \\
\text { Malaysia, (1970-2009) }\end{array}$ & $\begin{array}{l}\mathrm{Y} \leftrightarrow \mathrm{ECLR} \\
\mathrm{Y} \leftrightarrow \mathrm{EC}\end{array}$ & $\begin{array}{l}\text { ARDL, Bounds test, VECM } \\
\text { per capita } Y \text { and EC }\end{array}$ \\
\hline $\begin{array}{c}\text { Iyke (2015), } \\
\text { Nigeria, (1971-2011) }\end{array}$ & $E C \rightarrow Y$ & $\begin{array}{l}\text { JJ-Cointegration, VECM } \\
\text { per capita } Y \text { and EC }\end{array}$ \\
\hline $\begin{array}{c}\text { Kumar, Stauvermann \& Patel (2015), Gibraltar, } \\
(1996-2012)\end{array}$ & $E C \rightarrow Y$ & $\begin{array}{l}\text { ARDL, Bounds test, UECM } \\
\text { per capita } Y \text { and EC }\end{array}$ \\
\hline $\begin{array}{l}\text { Ogundipe, Akinyemi \& Ogundipe. (2016), Nigeria, } \\
\text { (1970-2013) }\end{array}$ & $\mathrm{Y} \rightarrow \mathrm{EC}$ & $\begin{array}{l}\text { JJ-Cointegration, VECM } \\
\text { per capita } Y \text { and EC }\end{array}$ \\
\hline
\end{tabular}

Note: Only Gurgul \& Lach (2012) was used quarterly data, the rest of the studies were used annual data.

However, seven studies have concluded that there is a feedback causality between $Y$ and EC. Such studies are Yoo (2005) for Korea, Ouedraogo (2010) for Burkina Faso, Ahamad \& Islam (2011) for Bangladesh, Kouakou (2011) for Ivory Coast, Shahbaz, Tang \& Shabbir (2011) for Portugal, Gurgul \& Lach (2012) for Poland, Tang \& Tan (2013) for Malaysia. Existing studies about countries under investigation can not offer a conclusive result regarding the way of causality between $Y$ and EC due to different methods, time periods, model specification and developed/developing countries conditions.

\section{Data}

This study employs the longest available annual data on two variables over the period from 1960 to 2014, with a total of 55 observations obtained from three data sources to examine the causality link between net EC and Y in Turkey. The variables are selected as; the net EC (in terms of gigawatt hours, GWh) obtained from the publication named as "TurkStat Statistical Indicators 1923-2013 issued by the Turkish Statistical Institute and latest data are obtained from the Turkish Electricity Transmission Company (TEIAS); and the 
real GDP (Y) used to proxy economic growth, measured at constant 2005 prices in U.S. dollars are obtained from the World Development Indicators (WDI) database online. Econometric software- namely, Eviews-9, TSP, and Stata-14 is used for the estimations.

Figure 1. The Plots of the Data Series (EC and Y) in Log Form

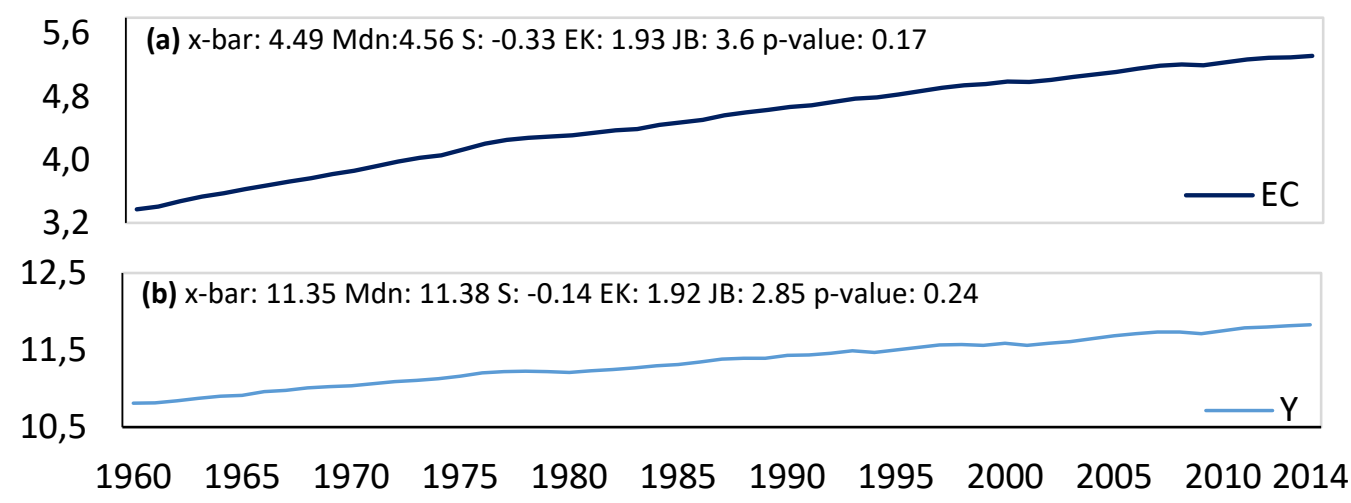

Figure 2. A Scatter Plot of The Variables (Y and EC)

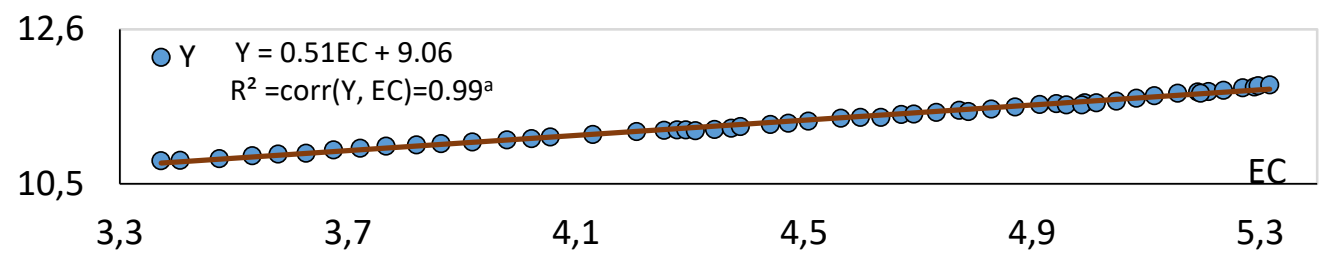

Many studies argued that using GDP is more appropriate than using GNP in analyzing causality association between total EC and the amount of aggregate domestic production. All variables are expressed in the logarithmic transformation. The descriptive statistics and plots of graphics for $Y$ and EC are presented in Figure 1a-b where means and medians are fairly close to each other. The positive excess kurtosis (EK: $1.93 / 1.92$ ) is close to 2 and less peaked than normal. The scatter plot of $Y$ and EC in Figure 2 displays a statistically significant linear relationship and perfect positive correlation between the variables visually in the form of a line graph. The negative skewness (S:-0.33/-0.14) is close to zero, implying that the distribution is approximately symmetric. The $h_{0}$ hypotheses of normality for the variables $Y$ and $E C$ can not be rejected at the $10 \%$ level due to the calculated test statistics do not exceed the critical values from the chi-sq(2) distribution in the JB (Jarque-Bera) test. The result is that the data set is normally distributed.

\section{Methods}

\subsection{Unit Root Tests}

In this study, various unit root tests (ADF, PP, DF-GLS, KPSS and ERS-PO) are utilized to determine stationarity of the two series. The Augmented Dickey-Fuller (1979) (ADF) and Phillips-Perron (1988) (PP) are asymptotically equivalent tests based on two models, whether to include a constant and a linear time trend in equations (1) and (2) and applied on the level and the first differences of all the variables. Here $\Delta$ : difference operator, $\delta, \omega, \beta$ : estimated coefficients, ut: error terms, and $t$ : time trend. The $h_{0}$ hypothesis is that $h_{0}: \omega=0$ $(Y t \sim 1(1))$ against $h_{1}: \omega<0(Y t \sim 1(0))$. 


$$
\begin{aligned}
& \Delta \mathrm{Y}_{\mathrm{t}}=\delta_{0}+\omega \mathrm{Y}_{\mathrm{t}-1}+\beta_{\mathrm{i}} \sum_{\mathrm{i}=1}^{\mathrm{P}} \Delta \mathrm{Y}_{\mathrm{t}-\mathrm{i}}+\mathrm{u}_{\mathrm{t}} \\
& \Delta \mathrm{Y}_{\mathrm{t}}=\delta_{0}+\delta_{1} \mathrm{t}+\omega \mathrm{Y}_{\mathrm{t}-1}+\beta_{\mathrm{i}} \sum_{\mathrm{i}=1}^{\mathrm{k}} \Delta \mathrm{Y}_{\mathrm{t}-\mathrm{i}}+\mathrm{u}_{\mathrm{t}}
\end{aligned}
$$

The PP test as a modified alternative (nonparametric) version of the ADF test corrects the existence of autocorrelation and heteroscedasticity in error terms (ut) by employing Newey-West covariance matrix estimator so that autocorrelation does not affect the asymptotic distribution of the test statistics. The DFGLS (1992) unit root test is considered as a more powerful and efficient test in small sample size. This test developed by Elliott, Rothenberg and Stock (ERS) is a modification of ADF unit root test based on generalized least squares (GLS). Kwiatkowski, Phillips, Schmidt and Shin (KPSS) (1992) developed a unit root test based on the residuals from the OLS regression is assumed to be (trend) stationary under the $h_{0}$ hypothesis. The ERS point-optimal (ERS-PO) (1996) unit root test developed by Elliott, Rothenberg-Stock. The ERS-PO test is considered as a powerful when trend components are present. In this study optimum lag lengths for the KPSS and PP are selected by the Newey-West bandwidth using the Bartlett kernel, and for the ADF, DF-GLS, ERS$\mathrm{PO}$ are selected by the BIC.

\subsection{ARDL Bounds Test}

The long run link between $Y$ and EC can be expressed by a reduced-form equation, as shown in (3). The ARDL Bounds test approach is a powerful method in a small or finite sample data to estimate the link between the variables, whether $Y$ and EC are cointegrated of order (1) or (0) or a mixture of both, or jointly cointegrated (Pesaran, Shin \& Smith, 2001: 290). This test first considers that all variables are endogenous. Then, it simultaneously estimates the short/long run coefficients in the ARDL $(p, q)$ model. The ARDL-UECM model which is a representation of equation (3) can be formulated in equation (4) as follows:

$$
\begin{aligned}
& \mathrm{Y}_{\mathrm{t}}=\beta_{0}+\beta_{1} \text { trend }+\sum_{\mathrm{i}=1}^{\mathrm{p}} \beta_{2 \mathrm{i}} \mathrm{Y}_{\mathrm{t}-\mathrm{i}}+\sum_{\mathrm{i}=0}^{\mathrm{q}} \beta_{3 \mathrm{i}} \mathrm{EC}_{\mathrm{t}-\mathrm{i}}+\mathrm{u}_{\mathrm{t}} \\
& \Delta \mathrm{Y}_{\mathrm{t}}=\beta_{0}+\beta_{1} \text { trend }+\sum_{\mathrm{i}=1}^{\mathrm{p}} \beta_{\mathrm{i}} \Delta \mathrm{Y}_{\mathrm{t}-\mathrm{i}}+\sum_{\mathrm{i}=0}^{\mathrm{q}} \delta_{\mathrm{i}} \Delta \mathrm{EC}_{\mathrm{t}-\mathrm{i}}+\mu_{\mathrm{i}} \mathrm{Y}_{\mathrm{t}-1}+\sigma_{\mathrm{i}} \mathrm{EC}_{\mathrm{t}-1}+\mathrm{u}_{\mathrm{t}}
\end{aligned}
$$

where, $\beta_{0}$ is constant, $\beta_{1}$ is a time trend, ut is a white noise error term. The two alternative ARDL models are estimated with a maximum order of lag set to 4 based on criterias of AIC, SIC and HQ. The first step of the ARDL model based on the F or standard Wald tests estimate the long run association between $Y$ and EC by OLS. The $h_{0}\left(h_{1}\right)$ hypothesis for an unrestricted intercept and a restricted time trend model is $h_{0}$ : $\beta_{1}=\mu=\sigma=0(\mu \neq 0$ or $\sigma \neq 0)$; for an unrestricted intercept and unrestricted trend model is $h_{0}: \mu=\sigma=0(\mu \neq 0$ or $\sigma \neq 0)$. If the estimated F-statistics is greater (less) than the upper (lower) critical bounds value, then the $h_{0}\left(h_{1}\right)$ hypothesis is rejected, it implies that there is cointegration (no cointegration) (Pesaran, Shin \& Smith, 2001: 298-299). If there is a long run association between $Y$ and EC, then an ARDL $(p, q)$ model is obtained from the equation (3). This study has a relatively small sample size $(n=55)$. There are two sets of critical values, one is computed by Pesaran, Shin \& Smith (2001) for the large sample size 500-1000, the other is computed by Narayan (2005) for the small sample size 30-80. 


\subsection{ARDL Bounds Test to Error Correction Model (ECM)}

The ARDL Bounds test to the ECM of Pesaran Shin \& Smith (2001) in a single cointegration is considered as more effective compare to the traditional Engle-Granger (1987) and Gregory-Hansen (1996) methods. After a long run link is determined in the equation (4), the ARDL Bounds test to ECM can be formulated as equation (5) to estimate the short run coefficients with the long run estimates: Here, $\omega$ and $\varphi$, are the short run coefficients, ECT is the error correction term derived from the equation (3), and $\tau$ is the speed of adjustment coefficient.

$$
\Delta \mathrm{Y}_{\mathrm{t}}=\alpha_{0}+\beta_{1} \text { Trend }+\sum_{\mathrm{i}=1}^{\mathrm{n}} \omega_{\mathrm{i}} \Delta \mathrm{Y}_{\mathrm{t}-\mathrm{i}}+\sum_{\mathrm{i}=1}^{\mathrm{m}} \phi_{\mathrm{i}} \Delta \mathrm{EC}_{\mathrm{t}-\mathrm{i}}+\tau \mathrm{ECT}_{\mathrm{t}-\mathrm{1}}+\mathrm{u}_{\mathrm{t}}
$$

\subsection{Unrestricted VAR (UVAR) Model}

Sims' (1980) UVAR model covering all variables in each equation estimated by OLS is still accepted as one of simple and flexible econometric methods to determine Granger causality and policy analysis in the time series literature. In the UVAR model consisting $Y$ and EC variables are jointly determined; lagged values of the endogenous variables are on the right-hand side of without exception equation. The estimated UVAR (2) model includes $2(\mathrm{k}$ ) lags of each variable in each equation. In a two-variable system, the number of coefficients in each equation is $5(1+2 k)$ and the total number is $10(2+4 k)$. In the VAR model in a matrix form shown in equation (6), where $\alpha_{10}$ and $\alpha_{11}$ are constants and only exogenous variables, $a_{11 i}, a_{12 i}, a_{21}$, and $a_{22 i}$ are the coefficients to be estimated.

$$
\left[\begin{array}{c}
Y_{t} \\
E C_{t}
\end{array}\right]=\left[\begin{array}{l}
\alpha_{10} \\
\alpha_{20}
\end{array}\right]+\sum_{i=1}^{k}\left[\begin{array}{ll}
a_{11 i} & a_{12 i} \\
a_{21 i} & a_{22 i}
\end{array}\right]\left[\begin{array}{c}
Y_{t-i} \\
E C_{t-i}
\end{array}\right]+\left[\begin{array}{l}
u_{1 t} \\
u_{2 t}
\end{array}\right]
$$

\section{Empirical Findings}

The findings of the unit root test are presented in Table 3. The results of KPSS, DF-GLS and ERS-PO tests considered as more powerful than the ADF and PP tests indicate that the two series are not level stationary, but they are the first difference stationarity at the $1 \%$ level of significance.

Table 3. The Results of the Unit Root Tests

\begin{tabular}{|c|c|c|c|c|c|}
\hline \multirow{2}{*}{ Test } & Model & $\mathbf{Y}$ & $\mathbf{E C}$ & $\Delta \mathbf{Y}$ & $\Delta$ EC \\
\hline \multirow{2}{*}{ ADF } & $\mathrm{C}$ & -1.10 & $-5.05^{\mathrm{a}}$ & $-7.42^{\mathrm{a}}$ & $-4.51^{\mathrm{a}}$ \\
\cline { 2 - 6 } & $\mathrm{C}+\mathrm{T}$ & -2.76 & -0.90 & $-7.51^{\mathrm{a}}$ & $-6.29^{\mathrm{a}}$ \\
\hline \multirow{2}{*}{$\mathrm{PP}$} & $\mathrm{C}$ & -1.25 & $-5.01^{\mathrm{a}}$ & $-7.42^{\mathrm{a}}$ & $-4.46^{\mathrm{a}}$ \\
\cline { 2 - 6 } & $\mathrm{C}+\mathrm{T}$ & -2.78 & -0.91 & $-7.54^{\mathrm{a}}$ & $-6.24^{\mathrm{a}}$ \\
\hline \multirow{2}{*}{ DF-GLS } & $\mathrm{C}$ & 2.88 & 0.38 & $-6.39^{\mathrm{a}}$ & $-4.51^{\mathrm{a}}$ \\
\cline { 2 - 6 } & $\mathrm{C}+\mathrm{T}$ & -2.35 & -0.74 & $-7.13^{\mathrm{a}}$ & $-5.75^{\mathrm{a}}$ \\
\hline \multirow{2}{*}{ KPSS } & $\mathrm{C}$ & 106.5 & 51.40 & $0.11^{\mathrm{a}}$ & 2.08 \\
\cline { 2 - 6 } & $\mathrm{C}+\mathrm{T}$ & 1.49 & 8.31 & $0.03^{\mathrm{a}}$ & $0.04^{\mathrm{a}}$ \\
\hline \multirow{2}{*}{ ERS-PO } & $\mathrm{C}$ & 59.91 & 30.16 & $1.22^{\mathrm{a}}$ & $1.19^{\mathrm{a}}$ \\
\cline { 2 - 6 } & $\mathrm{C}+\mathrm{T}$ & 12.21 & 42.36 & $3.87^{\mathrm{a}}$ & $4.29^{\mathrm{b}}$ \\
\hline
\end{tabular}

Note: Coefficients are significant at the $(1 \%)^{\mathrm{a}}$ and $(5 \%)^{\mathrm{b}}$ level, respectively. All ho hypotheses except KPSS test are non-stationary; in KPSS ho hypotheses are stationary. 
Table 4. The Results of The Bounds Test

\begin{tabular}{|c|c|c|c|c|}
\hline $\begin{array}{c}\text { Y=f(EC) } \\
\mathbf{k = 1}\end{array}$ & $\begin{array}{c}\text { Case IV } \\
\text { AIC }\end{array}$ & $\begin{array}{c}\text { Case V } \\
\text { AIC }\end{array}$ & $\begin{array}{c}\text { Case IV } \\
\text { SIC\&HQ }\end{array}$ & $\begin{array}{c}\text { Case V } \\
\text { SIC\&HQ }\end{array}$ \\
\hline $\begin{array}{c}\text { F-statistics } \\
(\chi 2 \text {-value) }\end{array}$ & $\begin{array}{c}9.69^{\mathrm{a}} \\
(29.07)^{\mathrm{a}}\end{array}$ & $\begin{array}{c}7.87^{\mathrm{b}} \\
(15.74)^{\mathrm{b}}\end{array}$ & $\begin{array}{c}11.10^{\mathrm{a}} \\
(33.30)^{\mathrm{a}}\end{array}$ & $\begin{array}{c}8.15^{\mathrm{b}} \\
(16.30)^{\mathrm{b}}\end{array}$ \\
\hline Table & Upper I (1) $_{\text {Case IV }}$ & $1 \%, 5 \%$ & 6.73 & 6.10 \\
\cline { 2 - 5 } & Lower I (0) & $1 \%, 5 \%$ & 5.15 & 4.68 \\
\hline Table & Upper I (1) & $1 \%, 5 \%$ & 9.63 & 7.30 \\
\cline { 2 - 5 } Case V & Lower I (0) & $1 \%, 5 \%$ & 8.74 & 6.56 \\
\hline
\end{tabular}

Note: Coefficients are significant at the $(1 \%)^{\mathrm{a}}$ and $(5 \%)^{\mathrm{b}}$ level, respectively. AIC: Akaike information criterion; SIC: Schwarz information criterion; HQ: Hannan-Quinn information criterion. Critical values for the I(1) series are referred to as upper bound critical values, while the critical values for I(0) series are referred to as the lower bound critical values.

Critical table values are extracted from Narayan (2005: 1988). For case IV, I(0): 1\%: 6.90, 5\%: 5.01 and $\mathrm{I}(1): 1 \% 7.53,5 \%$ 5.54. For case 5, I(0): 1\% 9.80, 5\% 6.93 and I(1): $1 \% 10.67, \% 5$ 7.79. Table 4 above shows that the calculated chi-sq tests are significant and the calculated F-statistics are greater than the upper bounds critical table values of both Pesaran Shin \& Smith (2001) and Narayan (2005), therefore the results of the bounds test indicate that the $h_{0}$ hypothesis of no cointegration is rejected.

Table 5. The Results of ARDL $(2,2)$ Model by AIC

\begin{tabular}{|c|c|c|c|l|}
\hline Variables & Coefficients & t-statistics & $\begin{array}{c}\text { Std. } \\
\text { Errors }\end{array}$ & $\begin{array}{c}\text { Diagnostic } \\
\text { Tests }\end{array}$ \\
\hline $\mathrm{Y}(-1)$ & $0.49^{\mathrm{a}}$ & 3.48 & 0.14 & $\mathrm{R}^{2}=0.99 / \mathrm{R}_{\mathrm{adj}}^{2}=0.99$ \\
\hline $\mathrm{Y}(-2)$ & 0.15 & 1.17 & 0.13 & $\mathrm{LM}(2)=0.91(0.41)$ \\
\hline $\mathrm{EC}$ & $0.81^{\mathrm{a}}$ & 8.33 & 0.10 & White $=1.35(0.25)$ \\
\hline $\mathrm{EC}(-1)$ & $-0.48^{\mathrm{b}}$ & -2.54 & 0.19 & $\mathrm{BGP}=1.16(0.34)$ \\
\hline $\mathrm{EC}(-2)$ & $-0.26^{\mathrm{b}}$ & -1.78 & 0.15 & $\mathrm{RESET}=0.013(0.91)$ \\
\hline Constant & $3.58^{\mathrm{a}}$ & 3.80 & 0.94 & $\mathrm{JB}=0.69(0.71)$ \\
\hline Trend & $0.005^{\mathrm{a}}$ & 4.11 & 0.00 & $\mathrm{ARCH}(2)=0.97(0.39)$ \\
\hline
\end{tabular}

Note: Coefficients are significant at the $(1 \%)^{\mathrm{a}}$ and $(5 \%)^{\mathrm{b}}$ level, respectively. Parentheses in the diagnostic tests are the probability values.

Table 6. The Results of ARDL $(1,1)$ Model by SIC\&HQ

\begin{tabular}{|c|c|c|c|c|}
\hline Variables & Coefficients & t-statistics & Std. Errors & Diagnostic Tests \\
\hline $\mathrm{Y}(-1)$ & $0.69^{\mathrm{a}}$ & 8.50 & 0.08 & $\mathrm{LM}(1)=2.58(0.11)$ \\
\hline $\mathrm{EC}$ & $0.85^{\mathrm{a}}$ & 9.11 & 0.09 & White $=1.21(0.32)$ \\
\hline $\mathrm{EC}(-1)$ & $-0.78^{\mathrm{a}}$ & -8.15 & 0.10 & $\mathrm{BGP}=0.99(0.42)$ \\
\hline Constant & $3.16^{\mathrm{a}}$ & 3.94 & 0.80 & $\mathrm{RESET}=0.44(0.51)$ \\
\hline Trend & $0.004^{\mathrm{a}}$ & 3.96 & 0.001 & $\mathrm{JB}=0.25(0.88)$ \\
\hline \multicolumn{2}{|c|}{$\mathrm{R}^{2}=0.99 / \mathrm{R}_{\mathrm{adj}}^{2}=0.99$} & $\mathrm{RSS}=0.009 / \mathrm{DW}=2.37$ & $\mathrm{ARCH}=1.92(0.17)$ \\
\hline
\end{tabular}

Note: Coefficients are significant at the $(1 \%)^{a}$ level. Parentheses in the diagnostic tests are the probability values. 
The existence of a long run, cointegration association between $\mathrm{Y}$ and $\mathrm{EC}$ suggests that there ought to be a causality in at least one direction. The results of ARDL $(2,2) / \operatorname{ARDL}(1,1)$ models in Table 5 and 6 show that the coefficient of EC is statistically significant at the $1 \%$ level. The diagnostic tests in Table 5 and 6 indicate no problem with serial correlation, heteroscedasticity, functional form and non-normality.

$R^{2}$ shows that $99 \%$ of the variation on $Y$ can be explained and suggests that such ARDL models fit the data reasonably well. The LM test of autocorrelation indicates that the error terms are not serially correlated. The White-BGP heteroscedasticity tests suggest that the disturbance term in the equation is homoscedastic. The Ramsey RESET test result shows that there is no specification error. The JB test shows the $h_{0}$ hypothesis of normally distributed residuals cannot be rejected. In the $\operatorname{ARDL}(2,2)$ and $\operatorname{ARDL}(1,1)$ models based on criterias of $\mathrm{AIC}$ and $\mathrm{BIC}$, the estimated coefficients of $\mathrm{EC}$, constant and trend variables are almost the same.

The estimated coefficients of the long-run link in the ARDL $(2,2)$ and ARDL $(1,1)$ models listed in Table 7 and 8 show that all coefficients are statistically significant at the $1 \%$ level. EC has a very high significant impact on $Y$. That is to say, higher EC accelerates $Y$ in the long run. To be precise, a $1 \%$ increase in $E C$ leads to $0.18 / 0.21 \%$ increase in economic growth. The results show that $E C$ has positive impact on $Y$ and a positive causality is moving from EC to $Y$. Due to the existence of a long run link between $Y$ and EC, the ARDL-ECM is estimated using the ARDL $(2,2)$ and ARDL $(1,1)$ based both on the criterias of AIC and SIC\&HQ.

Table 7. The Results of ARDL $(2,2)$ Long-Run Causal Link

\begin{tabular}{|c|c|c|c|}
\hline Variables & Coefficients & t-statistics & Std. Errors \\
\hline EC & $0.18^{\mathrm{a}}$ & 3.06 & 0.06 \\
\hline Constant & $10.11^{\mathrm{a}}$ & 48.84 & 0.21 \\
\hline Trend & $0.01^{\mathrm{a}}$ & 5.65 & 0.002 \\
\hline
\end{tabular}

Note: Coefficients are significant at the $(1 \%)^{\mathrm{a}}$ level.

Table 8. The Results of ARDL $(1,1)$ Long-Run Causal Link

\begin{tabular}{|c|c|c|c|}
\hline Variables & Coefficients & t-statistics & Std. Errors \\
\hline EC & $0.21^{\mathrm{a}}$ & 3.31 & 0.06 \\
\hline Constant & $10.05^{\mathrm{a}}$ & 46.78 & 0.21 \\
\hline Trend & $0.01^{\mathrm{a}}$ & 5.22 & 0.002 \\
\hline
\end{tabular}

Note: Coefficients are significant at the $(1 \%)^{\text {a }}$ level.

The results of ECM based on ARDL (2,2)/ARDL $(1,1)$ models in Table 9 and 10 reveal the short/long run Granger causality. A short run causality is running from EC to $\mathrm{Y}$. However, the reverse short run causality does not exit.

Table 9. The Results of Error Correction Model (ARDL $(2,2))$

\begin{tabular}{|c|c|c|c|}
\hline Variables & Coefficients & t-statistics & Std. Errors \\
\hline$\Delta \mathrm{Y}(-1)$ & -0.15 & -1.34 & 0.11 \\
\hline$\Delta \mathrm{EC}$ & $0.81^{\mathrm{a}}$ & 9.68 & 0.08 \\
\hline$\Delta \mathrm{EC}(-1)$ & $0.26^{\mathrm{c}}$ & 1.87 & 0.14 \\
\hline Constant & $3.59^{\mathrm{a}}$ & 5.51 & 0.65 \\
\hline Trend & $0.01^{\mathrm{a}}$ & 5.65 & 0.002 \\
\hline $\mathrm{ECT}(-1)$ & $-0.35^{\mathrm{a}}$ & -5.51 & 0.06 \\
\hline
\end{tabular}

Note: Coefficients are significant at the $(1 \%)^{\text {a }}$ level. 
Table 10. The Results of Error Correction Model (ARDL $(1,1)$ )

\begin{tabular}{|c|c|c|c|}
\hline Variables & Coefficients & t-statistics & Std. Errors \\
\hline$\Delta \mathrm{EC}$ & $0.85^{\mathrm{a}}$ & 10.46 & 0.08 \\
\hline Constant & $3.16^{\mathrm{a}}$ & 5.88 & 0.54 \\
\hline Trend & $0.004^{\mathrm{a}}$ & 3.96 & 0.001 \\
\hline $\mathrm{ECT}(-1)$ & $-0.30^{\mathrm{a}}$ & -5.89 & 0.05 \\
\hline
\end{tabular}

Note: Coefficients are significant at the $(1 \%)^{\text {a }}$ level.

The ECT series are derived from long-run co-integrating equation by the ARDL model. The coefficients of $E_{\mathrm{t}-1}(-0.30 /-0.35)$ show that long-run equilibrium is attainable and a long-run Granger causality is moving from real EC to $Y$, but the reverse does not. In the long run, $t$-statistics for the speed adjustment coefficients are statistically highly significant at the $1 \%$ level with an expected correct sign. The absolute values of the speed adjustment coefficients indicate that about $30 / 35 \%$ of shocks can be justified as a long run trend, and $30 / 35 \%$ of the disequilibrium of the previous year's shocks adjust back to the long run equilibrium. It implies that, in Turkey, $\mathrm{Y}$ and EC are co-integrated when $\mathrm{Y}$ serves as the dependent variable. The results in the Table 7 and 8 ( 9 and 10$)$ indicate that in the long (short) run $1 \%$ increase in EC leads to about $0.18 / 0.21 \%(1.07 / 0.85)$ increase in $\mathrm{Y}$. In the short/long run the immediate impact of changes in EC is the positive meaning that an increase in EC leads to an increase in $\mathrm{Y}$. The findings suggest that positive impact of EC on $\mathrm{Y}$ is relatively high in the short run compared to the long-run.

The five alternative unit root tests showed that the level data of the series does not satisfy the condition of covariance stationarity, but all the variables are stationary at the first difference data in Table 1. Therefore, in the UVAR Granger causality test, two variables are transformed into the first-difference form. The optimal lag length for the UVAR model is set to two where the VAR residuals are normally distributed, free of autocorrelation and no heteroscedasticity problem.

Table 11. The Results of The UVAR Analysis

\begin{tabular}{|c|c|c|c|c|c|c|}
\hline Model & $\begin{array}{c}\text { F- } \\
\text { statistics }\end{array}$ & $\begin{array}{c}\text { Chi-sq } \\
\text { statistics }\end{array}$ & $\begin{array}{c}\text { Causality } \\
\text { [Coefficients] }\end{array}$ & $\begin{array}{c}\text { Lag } \\
(\mathbf{k})\end{array}$ & $\mathbf{R}^{\mathbf{2}}$ & $\mathbf{R}_{\text {adj }}^{\mathbf{2}}$ \\
\hline $\mathrm{Y}=f(\mathrm{EC})$ & $5.06(0.08)^{\mathrm{c}}$ & $2.53(0.09)^{\mathrm{c}}$ & $\mathrm{EC} \rightarrow \mathrm{Y}[0.05]+$ & 2 & 0.22 & 0.15 \\
\hline $\mathrm{EC}=f(\mathrm{Y})$ & $0.62(0.54)$ & $1.23(0.54)$ & Neutral & 2 & 0.10 & 0.02 \\
\hline \multirow{2}{*}{$\begin{array}{c}\text { Diagnostic } \\
\text { Tests }\end{array}$} & $\begin{array}{c}\mathrm{AR} \text { Roots } \\
\text { max; } \text { min }\end{array}$ & White & $\mathrm{ARCH}$ & $\mathrm{JB}$ & $\mathrm{LM}$ & $\begin{array}{c}\mathrm{r} \\
\left(\mathrm{e}_{1}, \mathrm{e}_{2}\right)\end{array}$ \\
\cline { 2 - 7 } & $0.65 ; 0.27$ & $20.96(0.64)$ & $0.08(0.92)$ & $\begin{array}{c}14.28 \\
(0.11)\end{array}$ & $\begin{array}{c}<4.37 \\
(0.36)\end{array}$ & 0.76 \\
\hline
\end{tabular}

Note: Coefficients are significant at the $(10 \%)^{c}$ level. Values within the parentheses are the probability values.

The UVAR Granger causality test results for the endogenous variables in Table 11 show that there is a positive unidirectional Granger causality from EC to $Y$ at the $10 \%$ significance level in both $\mathrm{F}$ and chi-sq tests. Table 11 also reveals that in the model $(Y=f(E C))$, EC Granger-cause $Y$, and the inclusion of past values of $E C$ in the $Y$ equation provided a better explanation of current values of $Y$ than when excluded. The diagnostic tests in Table 11 indicate that the AR roots are less than 1 (inside the unit circle), the model has no instability problem. P-values of the White-ARCH-JB(Urzua)-LM- tests are more than the $10 \%$ level. That is, the variances of the error terms are constant, error terms are normally distributed, error terms have no autocorrelation and correlation coefficient between the error terms is 0.76 . The diagnostic tests show that there is no evidence of diagnostic problem with the UVAR model.

\section{The Cusum-Cusumsq Tests}

To reveal the stability in coefficient and variance of the regression error, the Cusum-Cusumsq tests proposed by Brown et al. (1975) are utilized as a test for detecting instability. A visual examination of the 
Cusum-Cusumsq graphics presented in Figure 3,4 and 5 is also useful to see model stability. The plots of Cusum-Cusumsq statistics stay within the $\% 5$ significance level, therefore estimated coefficients in the regressions are stable. Since the graphics can not reject the $h_{0}$ hypothesis, the UVAR and ARDL models have no structural stability or specification problem.

Figure 3. The Cusum-Cusumsq Tests in ARDL $(2,2)$
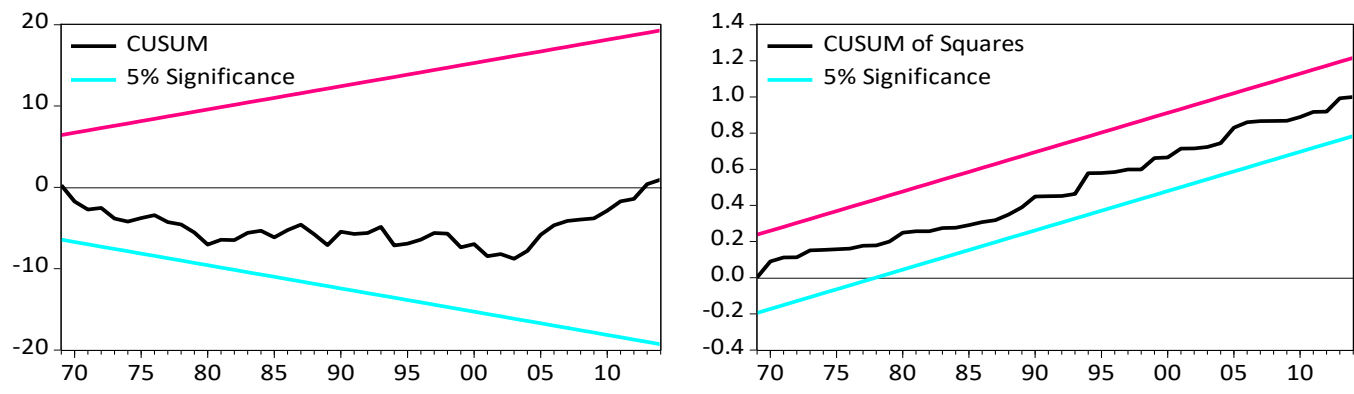

Figure 4. The Cusum-Cusumsq Tests in ARDL $(1,1)$
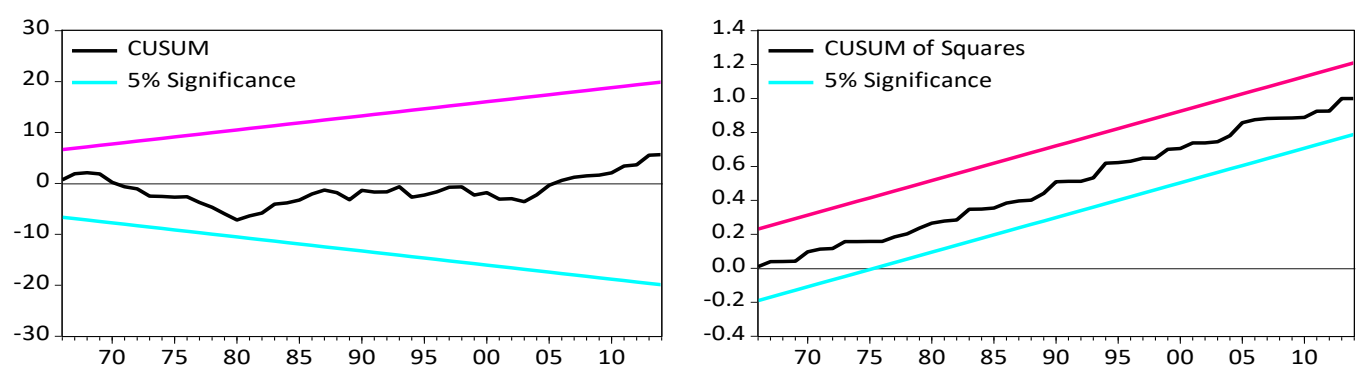

Figure 5. The Cusum-Cusumsq Tests in UVAR
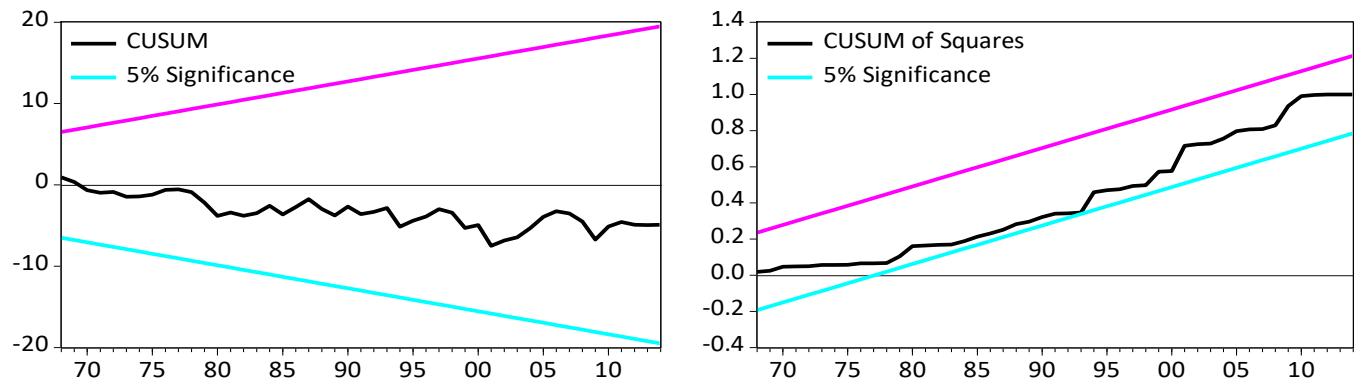

Additionally, Table 12 below shows the results of the Cusum-Cusumsq test statistics in the ARDL $(2,2)$ ARDL $(1,1)$ and UVAR models.

Table 12. The Results of The Cusum-Cusumsq Tests

\begin{tabular}{|c|c|c|c|c|}
\hline Models & $\begin{array}{c}\text { Cusum } \\
\text { Test Statistics }\end{array}$ & $\begin{array}{c}\text { P- } \\
\text { values }\end{array}$ & $\begin{array}{c}\text { Cusumsq } \\
\text { Test Statistics }\end{array}$ & $\begin{array}{c}\text { P- } \\
\text { values }\end{array}$ \\
\hline ARDL (2,2) & 0.68 & 0.28 & 0.09 & 0.99 \\
\hline ARDL (1,1) & 0.63 & 0.35 & 0.07 & 1.00 \\
\hline UVAR & 0.45 & 0.79 & 0.21 & 0.15 \\
\hline
\end{tabular}


The p-values of the Cusum-Cusumsq test statistics are higher than the $10 \%$ for all models suggest that the $h_{0}$ hypothesis of no structural break can not be rejected at the $10 \%$ significance level. Therefore, coefficients in all models over time have no instability problem.

The findings of this study based on the ARDL and UVAR methods support; the short run findings of Altnnay \& Karagol (2005); the long run findings of Karagol, Erbaykal \& Ertuğrul (2007) and Soytas \& Sarı (2006); the short and long run findings of Acaravcı (2010). Additionally, the results of this study are also unique from the earlier studies in that a positive unidirectional causality is moving from EC to $Y$ in the short/long run.

\section{A Short Summary and Conclusions}

It is generally accepted that there is a strong association between level of energy and level of major socio-economic variables in the literature. Electricity is an environmental energy source that can be used in every area of life. Numerous empirical studies conducted in both developed and developing countries indicate that level of energy, including electricity in a country played a crucial role in economic development. This study investigates the causality link between electricity consumption and economic growth in Turkey using the ARDL cointegration and UVAR causality models based on two variables. In this regard, the longest available annual time series data have been selected for the period of 1960-2014. However, the findings of this study should take into consideration with causation due to possibility of omitted variables. Alternative unit root tests are utilized to determine the stationarity of the variables. The conclusion is that the two series are stationarity at the first difference data. The coefficient of ECT in ECM is negative and significant, which means that it converges towards equilibrium. All diagnostic tests, including the Cusum-Cusumsq tests in the econometric models have the desired econometric properties. The results based on the bounds testing procedure indicate that a stable link exists between $\mathrm{Y}$ and $\mathrm{EC}$ in the short/long run. The overall results support growth hypothesis that a positive unidirectional causality is moving from EC to $Y$ in the short/long run, without feedback. That is, an increase on EC, ceteris paribus, gives rise to $\mathrm{Y}$, and the implementation of electricity conservation policy causes a slowdown in economic growth. Electricity consumption is an important source for the Turkish economy. Therefore, policy makers in Turkey should encourage investors to increase electricity supply, and implement energy promotion policies to increase in electricty consumption to maintain economic growth.

\section{References}

Acaravci, A. (2010). Structural breaks, electricity consumption and economic growth: Evidence from Turkey. Journal for Economic Forecasting, 2, 140-154.

Acaravci, A., \& Ozturk, I. (2012). Electricity consumption and economic growth nexus: A multivariate analysis for Turkey. Amfiteatru Economic, 14(31), 246-257.

Ahamad, M. G., \& Islam, A. N. (2011). Electricity consumption and economic growth nexus in Bangladesh: Revisited evidences. Energy Policy, 39(10), 6145-6150.

Akinlo, A. E. (2009). Electricity consumption and economic growth in Nigeria: Evidence from cointegration and cofeature analysis. Journal of Policy Modeling, 31(5), 681-693.

Aktas, C., \& Yılmaz, V. (2008). Causality between electricity consumption and economic growth in Turkey. ZKÜ Sosyal Bilimler Dergisi, 4(8), 45-54.

Altnay, G., \& Karagol, E. (2005). Electricity consumption and economic growth: Evidence from Turkey. Energy Economics, 27(6), 849-856.

Aslan, A. (2014a). Causality between electricity consumption and economic growth in Turkey: An ARDL bounds testing approach. Energy Sources, Part B: Economics, Planning, and Policy, 9(1), 25-31.

Aslan, A. (2014b). Electricity consumption, labor force and GDP in Turkey: Evidence from multivariate Granger causality. Energy Sources, Part B: Economics, Planning, and Policy, 9(2), 174-182.

Brown, R. L., Durbin, J., \& Evans, J. M. (1975). Techniques for testing the constancy of regression relationships over timewith discussion. Journal of Royal Statistical Society, Series B, 37, 150-155. 
Chandran, V. G. R., Sharma, S., \& Madhavan, K. (2010). Electricity consumption-growth nexus: The case of Malaysia. Energy Policy, 38(1), 606-612.

Dickey, D. A., \& Fuller, W. A. (1981). Likelihood ratio statistics for an autoregressive time series with a unit root. Econometrica, 49(4), 1057-1072.

Elliott, G., Rothenberg, T. J. \& Stock, J. H. (1996). Efficient tests for an autoregressive unit root. Econometrica, 64(4), 813-836.

Ghosh, S. (2002). Electricity consumption and economic growth in India. Energy policy, 30(2), 125-129.

Gokten, S., \& Karatepe, S. (2016). Electricity consumption and economic growth: A causality analysis for Turkey in the frame of import-based energy consumption and current account deficit. Energy Sources, Part B: Economics, Planning, and Policy, 11(4), 385-389.

Gurgul, H., \& Lach, L. (2012). The electricity consumption versus economic growth of the Polish economy. Energy Economics, 34(2), 500-510.

International Energy Agency (IEA). (2016). Energy Policies of IEA Countries-Turkey 2016 Review. Retrieved September 26, 2016, from https://www.iea.org/publications/freepub lications/publication/EnergyPoliciesofIEACountriesTurkey.pdf

Iyke, B. N. (2015). Electricity consumption and economic growth in Nigeria: A revisit of the energy-growth debate. Energy Economics, 51, 166-176.

Jumbe, C. B. (2004). Cointegration and causality between electricity consumption and GDP: empirical evidence from Malawi. Energy Economics, 26(1), 61-68.

Karagol, E., Erbaykal, E. \& Ertugrul, H. M. (2007). Türkiye'de ekonomik büyüme ile elektrik tüketimi ilişkisi: Sınır testi yaklaşımı. Doğuş Üniversitesi Dergisi, 8(1), 72-80.

Kouakou, A. K. (2011). Economic growth and electricity consumption in Cote d'Ivoire: Evidence from time series analysis. Energy Policy, 39(6), 3638-3644.

Kumar, R. R., Stauvermann, P. J., \& Patel, A. (2015). Nexus between electricity consumption and economic growth: A study of Gibraltar. Economic Change and Restructuring, 48(2), 119-135.

Kwiatkowski, D., Phillips, P. C. B., Schmidt, P., \& Shin, Y. (1992). Testing the null hypothesis of stationarity against the alternative of a unit root: How sure are we that economic time series have a unit root? Journal of Econometrics, 54(1), 159-178.

Ministry of Energy and Natural Resources (MENR). (2014). Energy statistics in Turkey. Retrieved Augst 12, 2016, from http://www.enerji.gov.tr/en-US/Pages/Electricity.

Ministry of Foreign Affairs (2016). Retrieved Augst 14, 2016, from http://www.mfa.gov.tr/tur kiye_nin-enerjistratejisi.tr.mfa

Mozumder, P., \& Marathe, A. (2007). Causality relationship between electricity consumption and GDP in Bangladesh. Energy Policy, 35(1), 395-402.

Narayan, P. K. (2005). The saving and investment nexus for China: Evidence from cointegration tests. Applied economics, 37(17), 1979-1990.

Narayan, P. K., \& Smyth, R. (2005). Electricity consumption, employment and real income in Australia evidence from multivariate Granger causality tests. Energy Policy, 33(9), 1109-1116.

Nazlıoglu, S., Kayhan, S., \& Adıguzel, U. (2014). Electricity consumption and economic growth in Turkey: Cointegration, linear and nonlinear Granger causality. Energy Sources, Part B: Economics, Planning and Policy, 9(4), 315-324.

Ogundipe, A., Akinyemi, O., \& Ogundipe, M. (2016). Electricity consumption and economic growth in Nigeria. International Journal of Energy Economics and Policy, 6(1), 134-143.

Ouedraogo, I. M. (2010). Electricity consumption and economic growth in Burkina Faso: A cointegration analysis. Energy Economics, 32(3), 524-531.

Pata, U. K., \& Terzi, H. (2016). The relationship between aggregated-disaggregated energy consumption and economic growth in Turkey. Business and Economics Research Journal, 7(4), 1-15.

Pempetzoglou, M. (2014). Electricity consumption and economic growth: A linear and nonlinear causality investigation for Turkey. International Journal of Energy Economics and Policy, 4(2), 263-273.

Pesaran M. H., \& Shin, Y. (1998). An autoregressive distributed-lag modelling approach to cointegration analysis. In Econometrics and Economic Theory in the Twentieth Century: The Ragnar-Frisch Centennial Symposium, Edited by S. Strom. Cambridge, UK: Cambridge University Press, 371-413. 
Pesaran, M. H., Shin, Y., \& Smith, R. J. (2001). Bounds testing approaches to the analysis of level relationships. Journal of Applied Econometrics, 16(3), 289-326.

Phillips, P. C. B., \& Perron, P. (1988). Testing for unit roots in time series regression. Biometrika, 75(2), 335-346.

Shahbaz, M., Tang, C. F., \& Shabbir, M. S. (2011). Electricity consumption and economic growth nexus in Portugal using cointegration and causality approaches. Energy Policy, 39(6), 3529-3536.

Shahbaz, M., \& Feridun, M. (2012). Electricity consumption and economic growth empirical evidence from Pakistan. Quality \& Quantity, 46(5), 1583-1599.

Shiu, A., \& Lam, P. L. (2004). Electricity consumption and economic growth in China. Energy Policy, 32(1), 47-54.

Sims, C. A. (1980). Macroeconomics and reality. Econometrica: Journal of the Econometric Society, 48(1), 1-48.

Soytas, U., \& Sarı, R. (2007). The relationship between energy and production: Evidence from Turkish manufacturing industry. Energy economics, 29(6), 1151-1165.

Tang, C. F., \& Tan, E. C. (2013). Exploring the nexus of electricity consumption, economic growth, energy prices and technology innovation in Malaysia. Applied Energy, 104, 297-305.

TEIAS. (2014). Faaliyet Raporu 2014. Retrieved September 10, 2016 from http://www.teias.gov .tr/FaaliyetRaporlari/faaliyetrap2014/2014.pdf

Terzi, H. (1998). Türkiye'de elektrik tüketimi ve ekonomik büyüme ilişkisi: Sektörel bir karşılaştırma. İktisat İşletme ve Finans, 13(144), 62-71.

TETAS. (2014). 2014 Yılı Sektör Raporu. Retrieved September 4, 2016 from http://www.tetas .gov.tr/File/?path=ROOT\%2f1\%2fDocuments\%2fSekt\%C3\%B6r+Raporu\%2fSektorRaporu2014.pdf

Topallı, N., \& Alagoz, M. (2014). Energy consumption and economic growth in Turkey: An empirical analysis. Selçuk Üniversitesi Sosyal Bilimler Enstitüsü Dergisi, 32, 151-159.

World Bank, (2016). World Development Indicators 2016. Retreived July 14, 2016, from http://data.worldbank.org/data-catalog/world-development-indicators

Yapraklı, S., \& Yurttancıkmaz Z. C. (2012). Elektrik tüketimi ile ekonomik büyüme arasındaki nedensellik: Türkiye üzerine ekonometrik bir analiz. C. Ü. İktisadi ve İdari Bilimler Dergisi, 13(2), 195-215.

Yoo, S. H. (2005). Electricity consumption and economic growth: Evidence from Korea. Energy Policy, 33(12), 1627-1632.

Yuan, J., Zhao, C., Yu, S., \& Hu, Z. (2007). Electricity consumption and economic growth in China: cointegration and cofeature analysis. Energy Economics, 29(6), 1179-1191. 
This Page Intentionally Left Blank 